\title{
Bacterial motility in the sea and its ecological implications
}

\author{
Hans-Peter Grossart* , Lasse Riemann**, Farooq Azam \\ Scripps Institution of Oceanography, University of California San Diego, La Jolla, California 92093-0202, USA
}

\begin{abstract}
Motility could be an important adaptation of heterotrophic bacteria and archaea, and it may have ecological and biogeochemical implications. However, the limited observations so far show that only a small fraction $(\leq 10 \%)$ of bacteria is motile. We report a systematic 10 mo long field study off the coast of La Jolla, California, as well as a mesocosm study to examine bacterial motility and its relationship to environmental variables. Dark-field microscopy revealed periods of sustained low (fall and winter, $<5$ to $25 \%$ ) and high (spring and summer, 40 to $70 \%$ ) percentages of motile bacteria (\% motile). Bacteria in natural seawater did not swim constantly nor at constant speeds; over $40 \%$ swam $<20 \%$ of the time, and showed bursts of motility. Percent motile showed a distinct diel pattern and was not significantly correlated with tidal cycle, chlorophyll $a$, or the abundance of algae, bacteria, and heterotrophic nanoflagellates. However, it was positively related with particulate organic carbon throughout diel sampling on 24 to 26 September 1997. During a mesocosm diatom bloom \% motile rose sharply as the bloom crashed, suggesting algal detritus may elicit motility. Enhanced \% motile resulted in increased colonization of living and dead algal cells by bacteria. Filtering seawater through a $1 \mu \mathrm{m}$ filter reduced \% motile, again suggesting the importance of particulate loci. Enrichment with dissolved organic nutrients enhanced \% motile only after $6 \mathrm{~h}$ but it rapidly $(\leq 1 \mathrm{~h})$ increased the time individual bacteria were swimming. Our results show that a variable fraction of marine bacteria is able to respond to loci of organic matter, e.g. organic particles and algae, and that motility underlies dynamic patterns of ecological relationships (symbiosis, competition, parasitism) between bacteria and algae. Since motility may enhance bacteria-organic-matter coupling it is likely to be an important variable in the oceanic carbon cycle.
\end{abstract}

KEY WORDS: Bacterial motility $\cdot$ Chemotaxis $\cdot$ Bacterial clustering $\cdot$ Microscale $\cdot$ Microbial loop · Dark-field microscopy $\cdot$ Nutrient enrichment $\cdot$ Carbon cycle

\section{INTRODUCTION}

Motility could be an important selective force in bacterial assemblages in the pelagic ocean. It could influence bacterial ecology and their role in oceanic biogeochemistry. The microenvironments of pelagic bacteria, long considered homogeneous, are now

\footnotetext{
Present addresses:

${ }^{*}$ Institute of Chemistry and Biology of the Marine Environment, University of Oldenburg, PO Box 2503, 26111 Oldenburg, Germany. E-mail: hgrossart@icbm.de

${ }^{* *}$ Freshwater Biological Laboratory, University of Copenhagen, 51 Helsingørsgade, 3400 Hillerød, Denmark
}

believed to be heterogeneously structured in terms of the spatial distribution of organic matter. It has been suggested that particulate loci of dissolved organic matter (DOM) production, such as live phytoplankton and detritus, create DOM gradients, and that the ability of heterotrophic bacteria to behaviorally respond to such gradients would be adaptive (Azam \& Ammerman 1984, Azam 1998). Thus, the behavioral response of pelagic bacteria to the spatial structure of the organic matter field at the microscale may significantly influence the nature and rates of bacteria-mediated organic matter transformations (Azam 1998). On the other hand, motility may increase the probability that the bacterium will be ingested by a protozoan (Monger 
et al. 1999) or infected by a phage (Bratbak et al. 1992). However, it was recently shown (Matz \& Jürgens 2001) that high speed swimming bacteria may reduce the ability of protozoa to graze on them. In addition, the energetic cost of motility may be significant for bacteria in a low nutrient seawater environment. Thus, it is not obvious, a priori, that motility would be a phenotype commonly adaptive and expressed by all pelagic bacteria.

Most marine bacterial isolates are motile in culture (ZoBell 1946). There have been only few quantitative studies of motility in natural assemblages and they found only a small fraction of bacterial communities to be motile ( $\leq 10 \%$; Mitchell et al. 1995). However, Mitchell et al. (1996) found that the motile fraction (\% motile) increased to $\sim 80 \%$ after $12 \mathrm{~h}$ of enrichment with tryptic soy broth. Cho \& Azam (unpubl.) used a capillary assay to measure \% motile bacteria off Scripps Pier. While \% motile was generally low, it rose to $33 \%$ on one occasion. Thus, it would seem that most bacteria in natural marine assemblages are non-motile except under specific environmental and nutritional conditions. It is of interest to know the conditions that elicit motility.

Bell \& Mitchell (1972) proposed 'phycosphere' as a region surrounding the algal cells to which bacteria are attracted and in which bacterial growth is stimulated by algal exudates. Azam \& Ammerman (1984) speculated that bacteria in seawater cluster around algae in a co-evolved commensal relationship; the alga exudes DOM while bacterial remineralization maintains high levels of inorganic nutrients in the microenvironment. Biddanda \& Pomeroy (1988) extended the concept to attraction of bacteria by detritus ('detritosphere'). Numerical simulations of bacterial clustering around phytoplankton in a turbulent ocean (Bowen et al. 1993) showed that bacteria could attain population densities orders-of-magnitude above background in the phycospheres. A recent model (Blackburn et al. 1997) predicts that chemotactic bacteria grow 50\% faster when gathered in loose clusters within nutrient patches. Thus, foraging strategies enabling bacteria to respond to DOM gradients could be adaptive.

We used dark-field microscopy to quantify bacterial motility in seawater assemblages. We also examined the relationships of bacterial motility to environmental parameters, to understand the ecological role and control of bacterial motility.

\section{MATERIALS AND METHODS}

Study site and sampling. Samples were collected off Scripps Pier $\left(32^{\circ} 53^{\prime} \mathrm{N}, 117^{\circ} 15^{\prime} \mathrm{W}\right)$, by lowering a $1 \mathrm{l}$ polycarbonate flask into the upper meter of the ca $6 \mathrm{~m}$ deep sea, from late August 1997 until the beginning of June 1998. On 28 October 1997, samples were also taken at other locations: Scripps Canyon, 1, 3, and 4 miles $(1.6,4.8$, and $6.4 \mathrm{~km}$ respectively) west of Scripps Pier, 0.5 and 1 mile $(0.8$ and $1.6 \mathrm{~km}$ respectively) north off La Jolla Cove. These were taken with a Niskin sampler bottle from the surface and $15 \mathrm{~m}$ depth. Samples were also taken in Mission Bay (boat ramp), on 29, 30, and 31 October 1997. We sampled for diel study on 24 to 26 September 1997 off Scripps Pier at 3 to $8 \mathrm{~h}$ intervals.

Bacterial motility. For microscopic examination of bacterial motility $\sim 0.2 \mathrm{ml}$ seawater was transferred, generally within 5 to $15 \mathrm{~min}$ of sampling, to a $0.5 \mathrm{~mm}$ thick plastic-coated depression slide. Motile bacteria were visualized with a Zeiss Standard 16 microscope with a dry dark-field condenser (0.7/0.85), a Planochrom lens (16/0.35) with a $2 \times$ magnification ring, and a $10 \times$ plano eyepiece. On 2 occasions (21 and 22 September), bacterial counts by dark-field microscopy (in a Petroff-Hauser Chamber; American Optical, Washington, DC) were compared with epifluorescence counts of DAPI stained samples. The counts by the 2 methods did not differ significantly $\left(2.48 \pm 0.7 \times 10^{6}\right.$ and $2.8 \pm 0.6 \times 10^{6} \mathrm{ml}^{-1}$ by dark-field vs $2.59 \pm 0.2 \times 10^{6}$ and $2.65 \pm 0.2 \times 10^{6}$ $\mathrm{ml}^{-1}$ by epifluorescence). Motility was determined in 2 ways: (1) Microscopic fields defined by an ocularmicrometer were observed for $1 \mathrm{~min}$ and all motile as well as non-motile bacteria were counted; and (2) microscope images were recorded with a video camera (CCD-300 TIFG; Dage MTI, NY), and motile and non-motile bacteria visualized with an image processor (IFG-300; Dage MTI) and a video screen (Hitachi, Japan). Both methods yielded similar \% motile on 29 and 30 October 1997 (58.8 \pm 1.5 and $56.9 \pm 0.9 \%$, respectively, when counting visually and $53.2 \pm 1.0$ and $53.0 \pm 0.2 \%$, respectively, with the video system).

Bacteria were observed for $1 \mathrm{~min}$, since longer observations did not increase \% motile: on 23 August 1997 $\%$ motile was 57.1, 61.0 and $59.6 \%$ based on observation periods of 1, 2 and 5 min, respectively. Standard deviation ( $\mathrm{n}=7$ and 8 ) was low (3.8 and $1.9 \%$ on 2 occasions). Bacteria tended to stick to the slide, therefore, we prepared a fresh slide for each 1 min observation of bacteria in a microscope field. Since we wanted to complete the counts soon after sampling, we reduced the replicates to 3 (standard deviation remained $<10 \%$, generally $<5 \%$ ). Bacteria moving even momentarily were scored motile. Brownian motion, in formalin-killed controls, was clearly differentiated from motility. Running time of motile bacteria was recorded by tracking individual cells for $5 \mathrm{~min}$. Whether temperature shift during microscopy (in situ = 
15 to $20^{\circ} \mathrm{C}$; during observation $=20$ to $22^{\circ} \mathrm{C}$ ) affected $\%$ motile was tested in 2 experiments (February 17 and 19): (1) seawater samples incubated for $12 \mathrm{~h}$ at 15.8 (ambient), 18.0 and $20.0^{\circ} \mathrm{C}$ yielded very similar \% motile; and (2) incubation for $12 \mathrm{~h}$ at 15 and $18^{\circ} \mathrm{C}$ did not significantly affect \% motile, but it increased (from 8.5 to $13.6 \%$ ) at $22^{\circ} \mathrm{C}$. Therefore, our winter measurements (low \% motile) may have been slightly overestimated.

Abundance of bacteria, heterotrophic nanoflagellates and algae. Two ml aliquots of unfiltered seawater were fixed with buffered formalin ( $2 \%$ final), stained with 4',6-diamidino-2-phenylindole (DAPI; $1 \mu \mathrm{g} \mathrm{ml}^{-1}$ final) for $3 \mathrm{~min}$, filtered onto $0.2 \mu \mathrm{m}$ poresized black polycarbonate filters (Nuclepore), and examined at $1250 \times$ by epifluorescence microscopy (Porter \& Feig 1980). For counting heterotrophic nanoflagellates (HNF) and algae, $10 \mathrm{ml}$ aliquots of seawater were fixed, stained and filtered onto 0.6 and 5.0 $\mu \mathrm{m}$ pore-sized polycarbonate filters (Nuclepore), respectively. Samples were usually counted within a few hours.

Particulate organic carbon (POC) and chlorophyll a (chl a). Seawater (0.5 to 11 ) was filtered onto pre-combusted glass fiber filters (GF/F; Whatman) and stored frozen until analysis. Samples for POC were kept in $\mathrm{HCl}$ fumes overnight, dried at $110^{\circ} \mathrm{C}$ for $1 \mathrm{~h}$, and measured by CHN analysis (Perkin Elmer, RodgauJügesheim, Germany). Chl a samples were extracted in $5 \mathrm{ml}$ cold, $96 \%$ ethanol for $24 \mathrm{~h}$ in the dark, filtered through GF/C filters and measured in a spectrophotometer (Perkin Elmer). The chl a content was calculated on the basis of absorbance at 750 and $665 \mathrm{~nm}$ (Jespersen \& Christoffersen 1987).

Bacterial carbon production. This was measured by ${ }^{3}$ H-leucine incorporation (Kirchman et al. 1985, Smith \& Azam 1992). Aliquots of $1.7 \mathrm{ml}$ unfiltered seawater were incubated in triplicate with L- $\left[4,5-{ }^{3} \mathrm{H}\right]$ leucine ( $20 \mathrm{nM}$ final) in $2.0 \mathrm{ml}$ polypropylene microcentrifuge tubes for $1 \mathrm{~h}$ at in situ temperature in the dark. Production was calculated as in Simon \& Azam (1989) assuming $20 \mathrm{fg} \mathrm{C}$ cell $^{-1}$ for free-living bacteria (Lee \& Fuhrman 1987) and $53 \mathrm{fg} \mathrm{C}^{\mathrm{C}} \mathrm{cell}^{-1}$ for attached bacteria (Simon et al. 1990).

Active electron transport system and nucleoidcontaining cells (NucC). Seawater was incubated with 5-cyano-2, 3-ditoyl tetrazolium chloride (CTC; Polysciences, $10 \mathrm{mM}$ final) for 1 to $2 \mathrm{~h}$ at in situ temperature in the dark (Rodriguez et al. 1992). Samples were formalin fixed (5\% final), counter-stained with DAPI (5 $\mu \mathrm{g}$ $\mathrm{ml}^{-1}$ ), and filtered onto $0.2 \mu \mathrm{m}$ pore size Nuclepore filters. CTC-active cells were visualized at $1250 \times$ in an epifluorescence microscope by their red fluorescence using a green filter set (excitation $546 \mathrm{~nm}$, barrier $590 \mathrm{~nm}$ ). Nucleoid-containing cells (NucC) were enu- merated by staining the samples with DAPI and destaining with 2-propanol with or without Triton X-100 (Zweifel \& Hagström 1995 and Choi et al. 1996, respectively).

Colony forming units (CFU). Fifty $\mu$ l seawater was streaked on ZoBell 2216 E agar plates (DIFCO). Bacterial colonies were counted after $3 \mathrm{~d}$ at room temperature in the dark.

Size fractionation. For different size classes of bacteria \% motile was determined after gravity-filtration of $10 \mathrm{ml}$ seawater through 1.0, 0.8, 0.6 and $0.4 \mu \mathrm{m}$ Nuclepore filters, and counting total and motile bacteria in each filtrate. Experiments were done with samples from Mission Bay (31 October 1997) and Scripps Pier (1 and 3 November 1997).

Shear stress. To determine the effect of shear stress on motility we treated surface samples off Scripps Pier in 2 ways: (1) samples were shaken by hand for $\leq 3 \mathrm{~min}$; and (2) samples were blended at high speed for $\leq 3 \mathrm{~min}$ (Ultra Blend, Rival, China) to shear flagella (Stocker \& Campbell 1959). We tested the effect of blending on viability by comparing CFUs before and after blending for 5 to $300 \mathrm{~s}$.

Removal of $>\mathbf{1} \boldsymbol{\mu m}$ particles. Effects of removing particles on \% motile was examined by incubating 50 $\mathrm{ml}$ of $1.0 \mu \mathrm{m}$ Nuclepore filtered seawater. All incubations were done in triplicates at in situ temperature for $16 \mathrm{~h}$.

Enrichment experiments. Live or killed diatoms: Particles $>1 \mu \mathrm{m}$ were removed by Nuclepore filtration. Living or dead Thalassiosira weissflogii, at 0 (control) or 1000 cells ml ${ }^{-1}$ were added to aliquots of the filtrate. Percent motile was determined periodically over $22 \mathrm{~h}$.

Peptone or peptone + glucose: Fifty ml seawater samples were enriched with peptone $\left(1 \mathrm{~g} \mathrm{l}^{-1}\right)$ or a mixture of peptone + glucose $\left(0.054\right.$ or $\left.5.41 \mathrm{mg} \mathrm{l}^{-1}\right)$ and incubated in $100 \mathrm{ml}$ glass flasks for $\leq 21 \mathrm{~h}$ at various temperatures in the dark. All samples were in triplicate along with an un-enriched control.

Inorganic nutrients: Seawater samples off Scripps were enriched with inorganic nutrients and trace metals at the level of $f / 2$ medium (Guillard 1975).

Mesocosm experiment. On 3 December 1997, surface seawater was collected off Scripps, filtered through a $33 \mu \mathrm{m}$ nylon mesh and incubated in 2081 polyethylene tanks (Nalgene) at 16.9 to $18.6^{\circ} \mathrm{C}$ in a $12: 12 \mathrm{~h}$ light:dark cycle with light intensities of 185 to $235 \mu \mathrm{E} \mathrm{m} \mathrm{m}^{-2} \mathrm{~s}^{-1}$. The seawater in the tanks was enriched with $\mathrm{NaH}_{2} \mathrm{PO}_{4}\left(0.79 \mu \mathrm{M}\right.$ final), $\mathrm{Na}_{2} \mathrm{SiO}_{3}$ (10.5 $\mu \mathrm{M}$ final), and $\mathrm{NaNO}_{3}$ or $\mathrm{NH}_{4} \mathrm{Cl}(10.5 \mu \mathrm{M}$ final). Bacterial motility, abundance, production, ectohydrolase activities, POC and chl a were measured daily. Details of the mesocosm experiment on microbial and nutrient dynamics are reported in Riemann et al. (2000). 


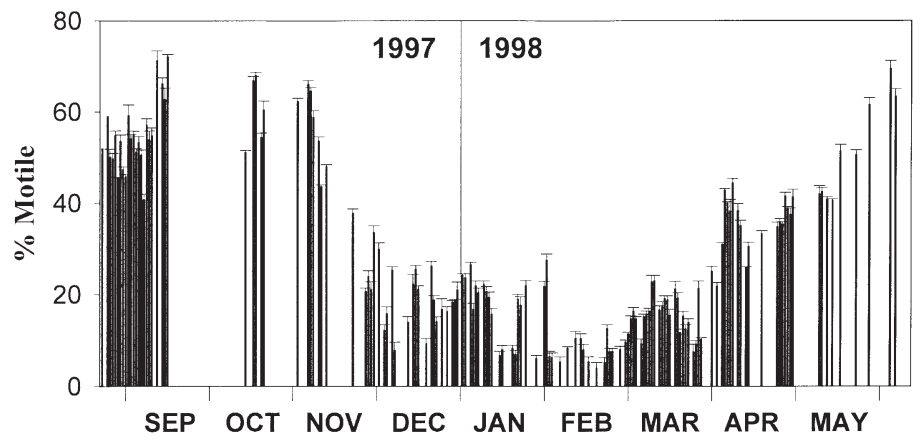

Fig. 1. Motility in natural bacterial assemblages (\% motile) in surface waters off Scripps from August 1997 to June 1998. Samples were counted by dark-field microscopy (for details see 'Materials and methods')

\section{RESULTS}

\section{Bacterial motility and its spatial and temporal variation}

Natural bacterial assemblages off Scripps Pier showed a regular temporal pattern in \% motile from August 1997 to June 1998 (Fig. 1). Motility was highest in September to October, declined during November, remained lowest in December to February $(<5$ to $25 \%)$, and increased from March to June $(<5$ to $>60 \%$ ). Samples were generally taken at 09:00 $\mathrm{h}$ to avoid diel effects. High \% motile in summer was also found at stations $\leq 4$ miles $(6.4 \mathrm{~km})$ offshore and at $15 \mathrm{~m}$ depth (51 to 64.6\%); \% motile in Mission Bay (29 and 30 October 1997) was lower (Table 1). In March to April 1998, during the development of a phytoplankton bloom (dominated by the dinoflagellate Prorocentrum micans), the peak in \% motile followed peaks in chl a by Day 3 and in POC by Day 2 . However, no significant correlations were found throughout the whole study between \% motile and the following variables POC, chl $a$, abundance of bacteria, heterotrophic nanoflagellates or algae, cell-specific bacterial production or tidal cycle. Changes in \% motile roughly followed variations in seawater temperature and both variables were weakly correlated to each other $\left(r^{2}=0.31, n=150\right)$.

Percent motile showed a distinct diel pattern (Fig. 2) with maximum $(\leq 63.1 \%)$ in the afternoon/evening and minimum $(\geq 40.8 \%)$ shortly before the sunrise. During the diel study $\%$ motile was positively correlated to POC $\left(\mathrm{r}^{2}=\right.$ 0.817, $\mathrm{n}=11$ ). Cell-specific bacterial production also showed a diel cycle with peaks following those in \% motile in late afternoon and evening; however, the 2 variables were not correlated $\left(\mathrm{r}^{2}=\right.$ $0.03, \mathrm{n}=11)$. Bacterial motility was positively correlated to CFU $\left(\mathrm{r}^{2}=0.678, \mathrm{n}=12\right)$ and to abundance of heterotrophic nanoflagellates $\left(\mathrm{r}^{2}=\right.$ 0.448, $\mathrm{n}=15)$. In contrast, \% motile was

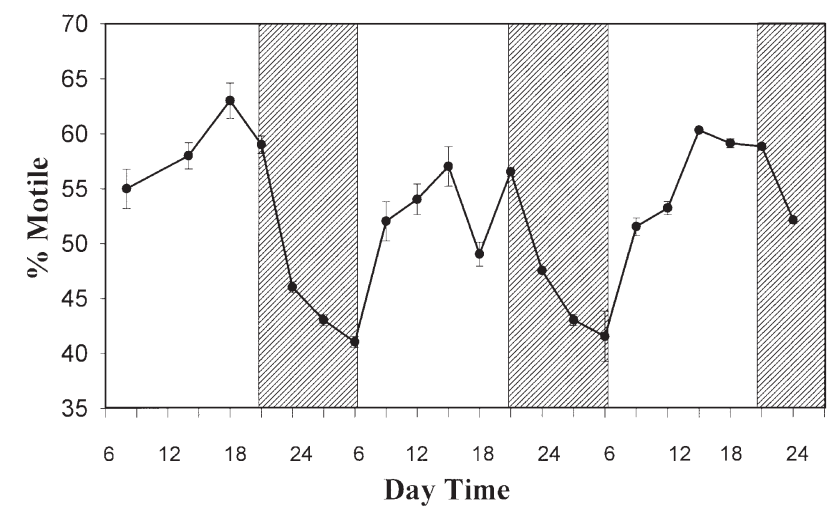

Fig. 2. Diel pattern of motility in natural bacterial assemblages (\% motile) in surface waters off Scripps on 23 to 25 October 1997. Samples were counted by dark-field microscopy (for details see 'Materials and methods')

Table 1. Bacterial abundance and \% motile at different locations and depths $(\mathrm{n}=3)$. Note: 1 mile $\approx 1.609 \mathrm{~km}$

\begin{tabular}{|lcccc|}
\hline Location & $\begin{array}{c}\text { Date } \\
\text { (Oct 1997) }\end{array}$ & $\begin{array}{c}\text { Depth } \\
(\mathrm{m})\end{array}$ & $\begin{array}{c}\text { Bacterial abundance } \\
\left(10^{6} \mathrm{cells} \mathrm{ml}^{-1}\right)\end{array}$ & $\begin{array}{c}\text { Bacterial motility } \\
(\%)\end{array}$ \\
\hline Scripps Canyon & 28 & 0 & $1.039 \pm 0.073$ & $64.6 \pm 0.72$ \\
1 mile west of Scripps Canyon & 28 & 0 & $0.925 \pm 0.076$ & $64.1 \pm 1.87$ \\
1 mile west of Scripps Canyon & 28 & 15 & $0.826 \pm 0.047$ & $62.0 \pm 1.23$ \\
4 miles west of Scripps Canyon & 28 & 0 & $0.656 \pm 0.075$ & $57.5 \pm 2.20$ \\
4 miles west of Scripps Canyon & 28 & 15 & $0.651 \pm 0.088$ & $60.1 \pm 0.86$ \\
3 miles off Scripps Pier & 28 & 0 & $0.769 \pm 0.080$ & $61.9 \pm 1.60$ \\
1 mile off La Jolla Cove & 28 & 0 & $0.902 \pm 0.065$ & $53.7 \pm 0.58$ \\
0.5 miles off La Jolla, Kelp & 28 & 0 & $1.029 \pm 0.076$ & $51.0 \pm 0.44$ \\
Mission Bay boat ramp & 29 & 0 & $1.890 \pm 0.170$ & $23.9 \pm 1.59$ \\
Mission Bay boat ramp & 30 & 0 & $1.940 \pm 0.110$ & $22.8 \pm 0.65$ \\
Mission Bay boat ramp & 30 & 0 & $1.900 \pm 0.060$ & $25.9 \pm 2.40$ \\
\hline
\end{tabular}


inversely related to bacterial abundance. It was highest $\left(\leq 1.45 \times 10^{6}\right.$ cells $\left.\mathrm{ml}^{-1}\right)$ in the morning and lowest $\left(\geq 0.95 \times 10^{6}\right.$ cells ml $\left.^{-1}\right)$ in the evening. During the diel study \% motile was also negatively correlated to chl a $\left(\mathrm{r}^{2}=0.643, \mathrm{n}=10\right)$, but not to algal number $\left(\mathrm{r}^{2}=0.216\right.$, $\mathrm{n}=11)$. It was independent of the tidal cycle $\left(\mathrm{r}^{2}=\right.$ $0.054, \mathrm{n}=11)$.

\section{Factors controlling bacterial motility}

\section{Cell size}

Size fractionation showed that the $<0.4 \mu \mathrm{m}$ size class contained a much lower \% motile than the total sample, both in Mission Bay $(<0.4 \mu \mathrm{m}=15.7 \%$, total $=$ $25.9 \%)$ and off Scripps Pier $(<0.4 \mu \mathrm{m}=14.7$ and $13.6 \%$, total $=53.6$ and $52.0 \%$, for 1 and 3 November 1997 , respectively).

\section{Flagellation}

Motility was irreversibly eliminated by blending the samples for $>120 \mathrm{~s}$, without a reduction in plating efficiency (data not shown). There was no change in \% motile when samples were shaken by hand for $3 \mathrm{~min}$.

\section{Particles}

Removal of particles by filtering seawater through $1 \mu \mathrm{m}$ Nuclepore filters decreased \% motile (from 60 to $<40 \%$ ). Since the $>1 \mu \mathrm{m}$ particles would have included phytoplankton we wondered if excluding photosyn-

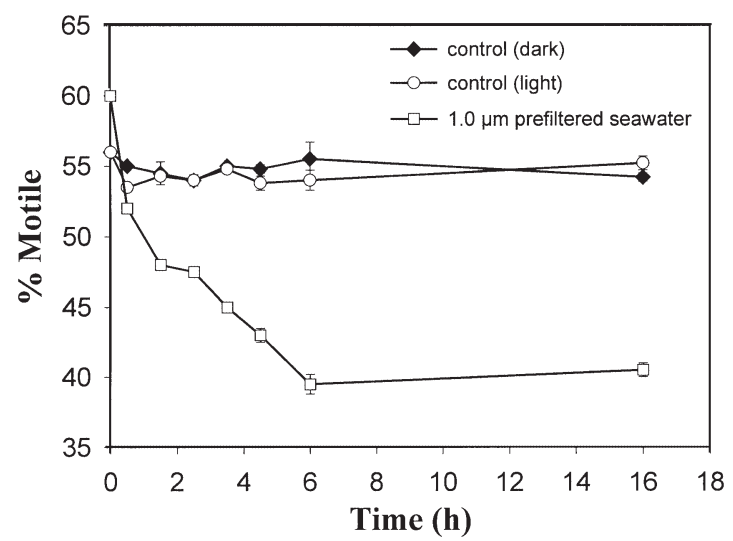

Fig. 3. Bacterial motility ( $\%$ motile) in $1 \mu \mathrm{m}$ prefiltered and natural seawater samples off Scripps Pier incubated for $16 \mathrm{~h}$ at in situ temperature on 4 to 5 September 1997. The unfiltered control was incubated in the light and dark to test whether photosynthesis (without particle removal; by dark incubations) would change $\%$ motile thesis alone, by dark incubations of whole seawater samples, would change \% motile; it did not (Fig. 3). In another experiment, adding live or lysed Thalassiosira weissflogii to $1 \mu \mathrm{m}$ filtered seawater enhanced $\%$ motile (Fig. 4a). Since the response to long (16 h) incubations with T. weissflogii may have been due to species shifts, we tested the response of 3 isolates of motile marine bacteria. It varied with the isolate (Fig. 5). A sharp decrease in \% motile occurred in 1 isolate (LHAT 5) whereas the other 2 isolates (SWAT 8 and SWAT 9) showed enhanced \% motile. This difference in motility was also reflected in lower \% attachment of LHAT 5 to the added detritus.
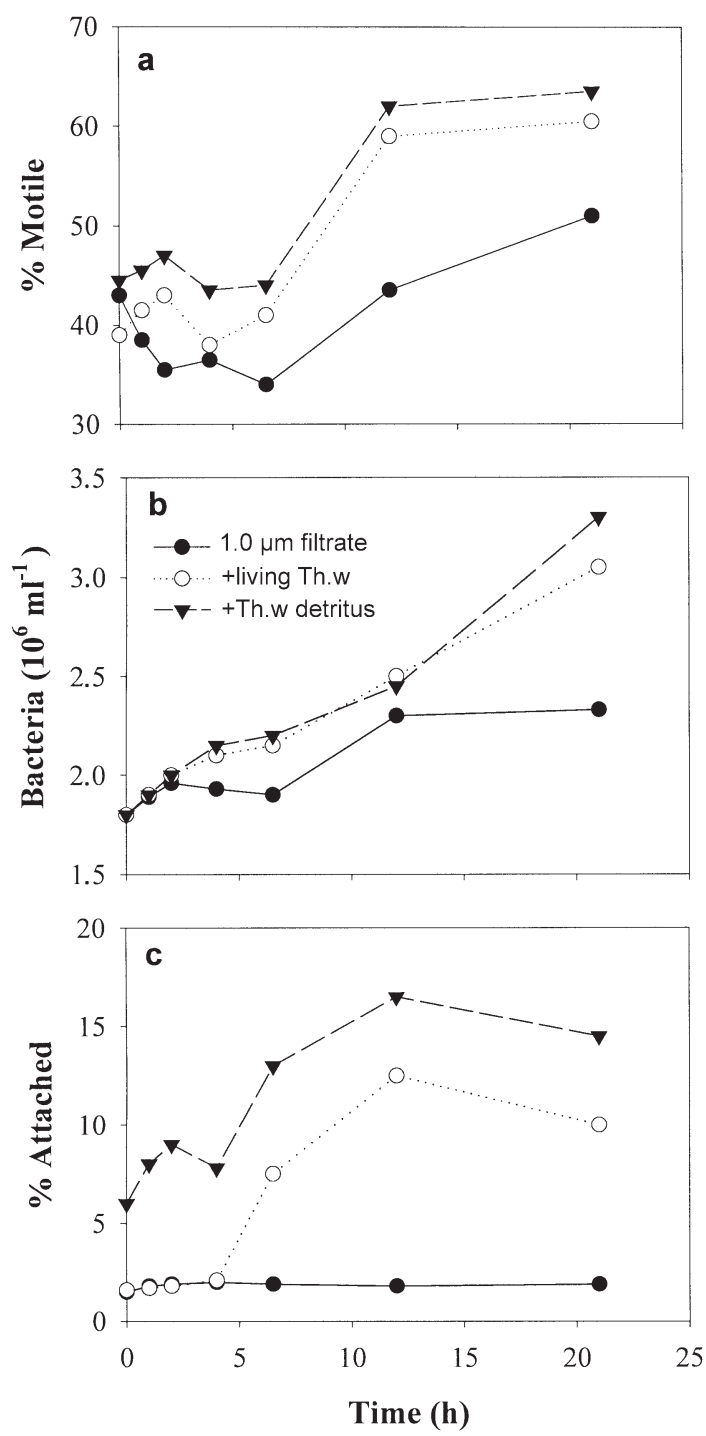

Fig. 4. Changes in (a) bacterial motility (\% motile), (b) bacterial abundance, and (c) \% of attached bacteria (\% attached) in $1.0 \mu \mathrm{m}$ prefiltered seawater samples off Scripps Pier incubated without and with living or dead Thalassiosira weissflogii for $22 \mathrm{~h}$ at in situ temperature. Th.w: T. weissflogii 

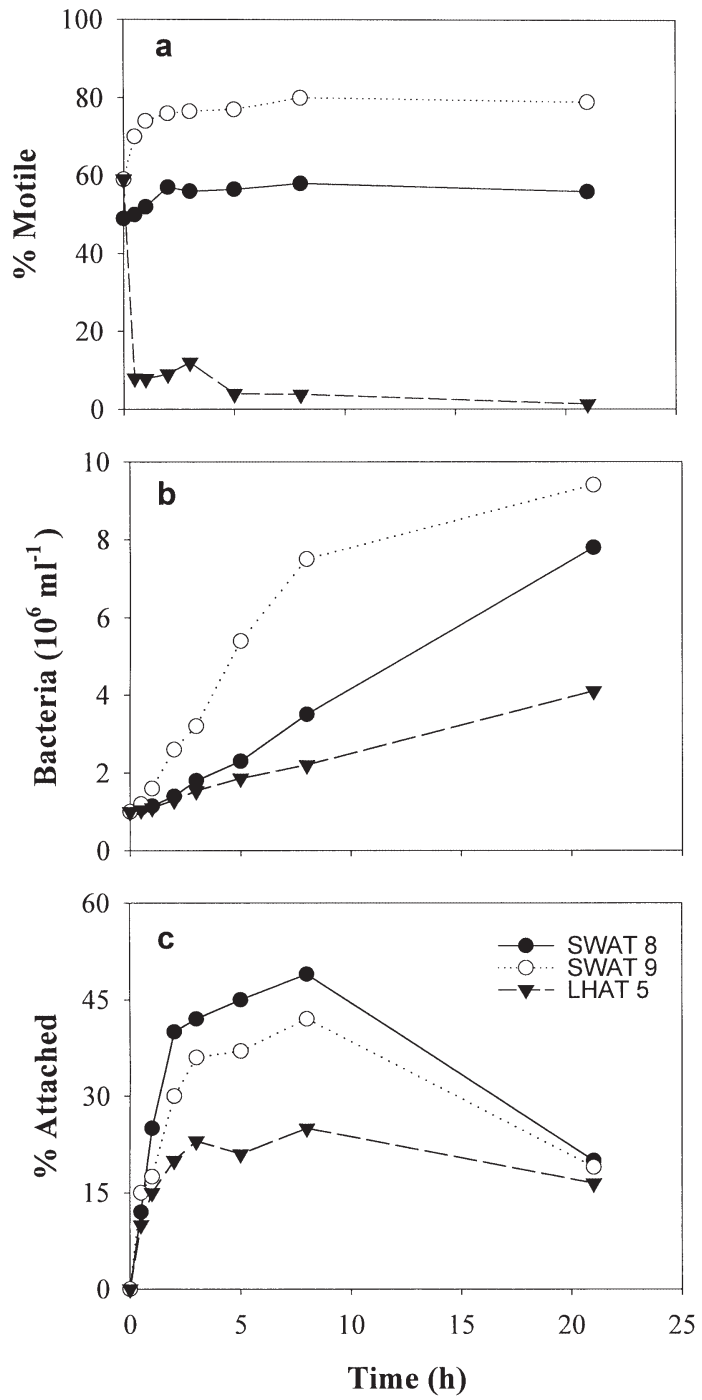

Fig. 5. Changes in (a) bacterial motility (\% motile), (b) bacterial abundance, and (c) percentage of attached bacteria (\% attached) in 3 bacterial cultures (SWAT 8 and 9, LHAT 5) (for further details see text) after the addition of living or dead Thalassiosira weissflogii

\section{Nutrient enrichment}

Incubating seawater with high levels of glucose or peptone $\left(100 \mathrm{mg} \mathrm{l}^{-1}\right)$ for $1 \mathrm{~h}$ did not increase \% motile but it changed bacterial behavior, prolonging the percentage of time bacteria were motile. The fraction of bacteria that were motile for $80 \%$ of the $5 \mathrm{~min}$ observation time increased from $27 \%$ (control) to $62 \%$ (glucose) and $72 \%$ (peptone) (not shown). Enrichment (3.7 $\mathrm{g} \mathrm{l}^{-1}$ ZoBell $2216 \mathrm{E}$ ) led to an increase in motile bacteria $(>80 \%, 12 \mathrm{~h})$ approximately equal to total increase in bacteria. Finally, enrichment with inorganic nutrients or trace metals did not change \% motile, even after $16 \mathrm{~h}$.
Physiological state

CTC-positive cells were 10.7 and $8.5 \%$ of the total, whereas the corresponding \% motile was 54.4 and $60.4 \%$ on 9 and 10 October 1997, respectively. Not surprisingly, motility ceased in CTC treatment, since motility requires a sustained energy supply. Enrichment and long incubation (1 $\mathrm{g} \mathrm{l}^{-1}$ peptone, $\left.16 \mathrm{~h}\right)$, enhanced both the CTC-positive (91.1\%) and \% motile $(85.5 \%)$. We also compared \% motile with \% nucleoidcontaining cells (NucC) by Zweifel \& Hagström (1995) and Choi et al. (1996) protocols. NucC were much lower (32 and $34 \%$ ) than \% motile (60.4\%) (data not shown).

\section{Mesocosm experiments}

Addition of inorganic nutrients to metazoa-free seawater caused a bloom dominated by Thalassiosira sp. The intense bloom (chl a $\sim 20 \mu \mathrm{g} \mathrm{l}^{-1}$; Fig. 6) and its subsequent demise (rapid rise in detrital POC) were accompanied by a sharp increase in \% motile. Details of the mesocosm experiment are in Riemann et al. (2000), but they did not report on bacterial motility. Here, we focus on variables related to bacterial motility, in 2 replicate mesocosms.

Bacterial motility remained at $\sim 20 \%$ in both mesocosms early in the bloom (Days 1 to 6) even as chl $a$ and total and attached bacteria roughly doubled (Figs 6 \& 7; see also Fig. 1 in Riemann et al. 2000). Subsequently, $\%$ motile increased in 2 steps, first to $\sim 30 \%$ as chl a rose sharply (Days 6 to 9), followed by a very rapid increase to $75 \%$ on Day 12 accompanying a rise in detrital POC and POC:chl a ratio (Fig. 6). The increase in $\%$ motile paralleled the increase in abundance and production of bacteria, as well as protease activity, on particles (Fig. 7; see also Fig. 2 in Riemann et al. 2000).

Specific growth rates of free-living bacteria did not significantly change during the period of a large increase in \% motile; it remained $<1 \mathrm{~d}^{-1}$ in both mesocosms. High biomass-specific growth rates of attached bacteria coincided with peaks in cell-specific lipase and protease activities on particles (Day 11). The strong increase of biomass-specific growth rate and lipase as well as protease activity on Day 11 paralleled the concentration of detrital POC (Fig. 7). Total phosphatase activity strongly increased on Day 8 as phosphate concentrations dropped below $1 \mu \mathrm{M}$ indicating increased nutrient stress to the phytoplankton (Riemann et al. 2000). Bacterial colonization of diatoms increased over time in parallel with increase in \% motile (Fig. 8). Highest bacterial colonization of living algal cells (>90\%) occurred during the decline of the phytoplankton bloom when detrital POC became highly abundant. 
Fig. 6. Changes in $(a, b)$ bacterial motility (\% motile) and chlorophyll $a(\mathrm{chl} a)$ and POC as well as (c,d) POC: chl a ratio and detrital POC throughout 2 parallel mesocosm experiments (Tank 1, Tank 3; for further details see 'Results; Mesocosm experiments')
Fig. 7. Changes in $(a, b)$ bacterial motility (\% motile) and abundance of free-living and attached bacteria as well as $(\mathrm{c}, \mathrm{d})$ detrital POC and proteolytic activity of free-living and attached bacteria throughout 2 parallel mesocosm experiments (Tank 1, Tank 3)
Tank 1

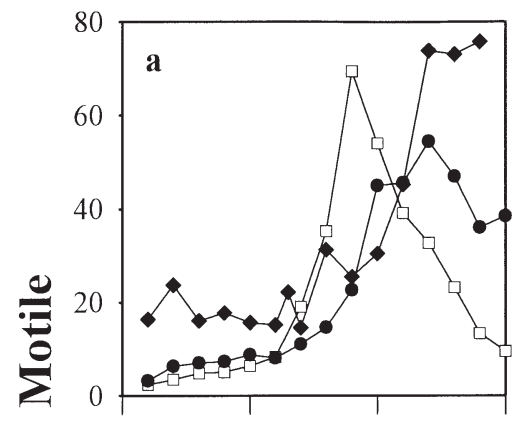

बे

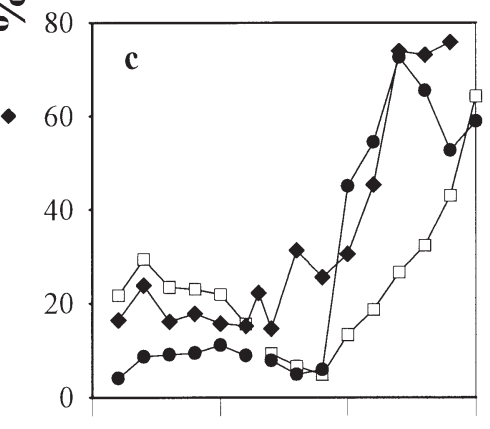

0

10

150

Time (d)

Tank 1
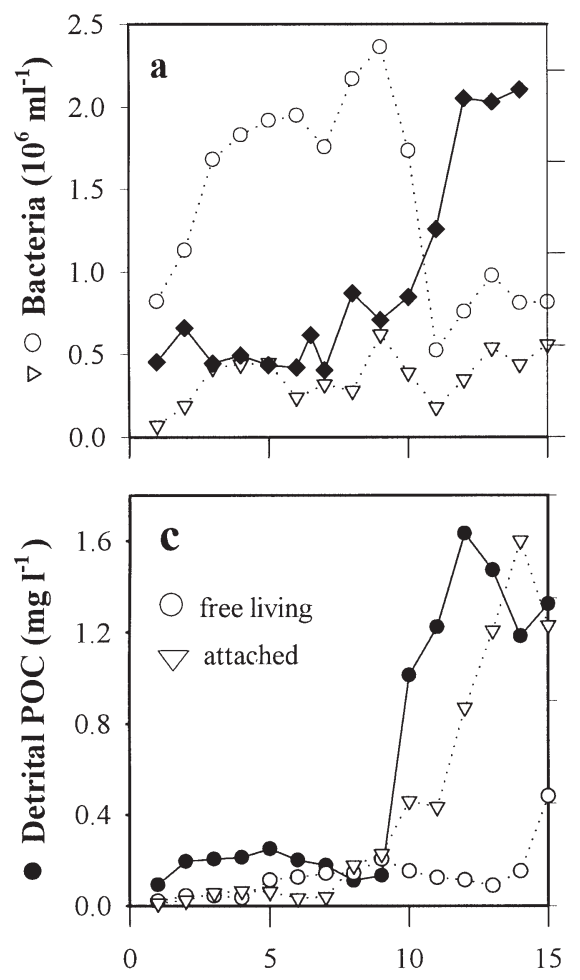

Tank 3
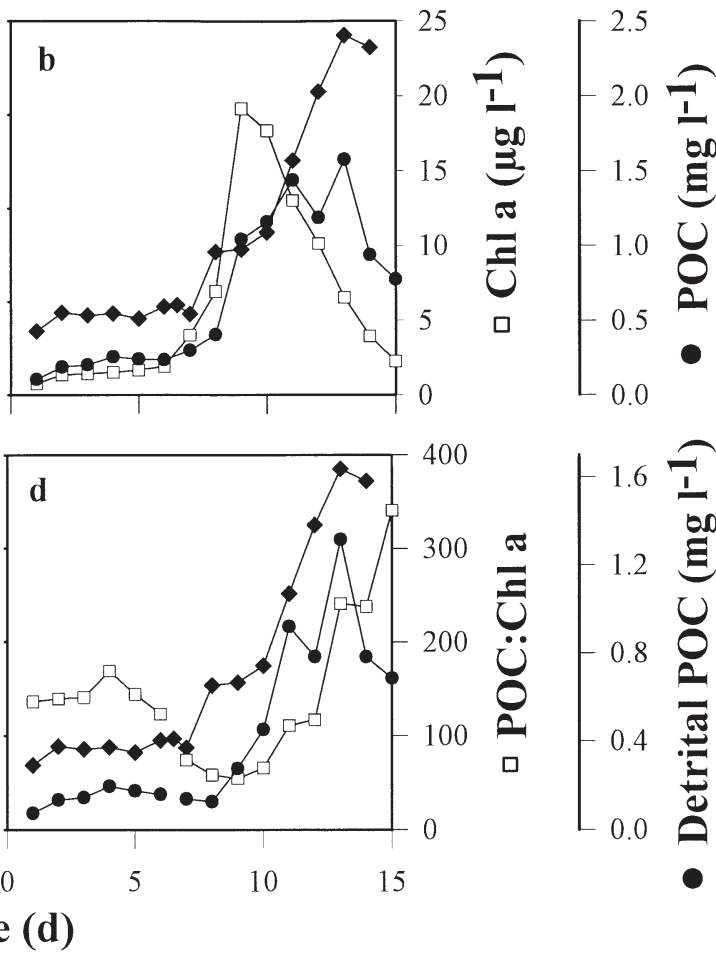

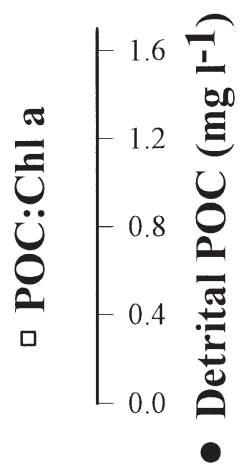




\section{Tank 2}
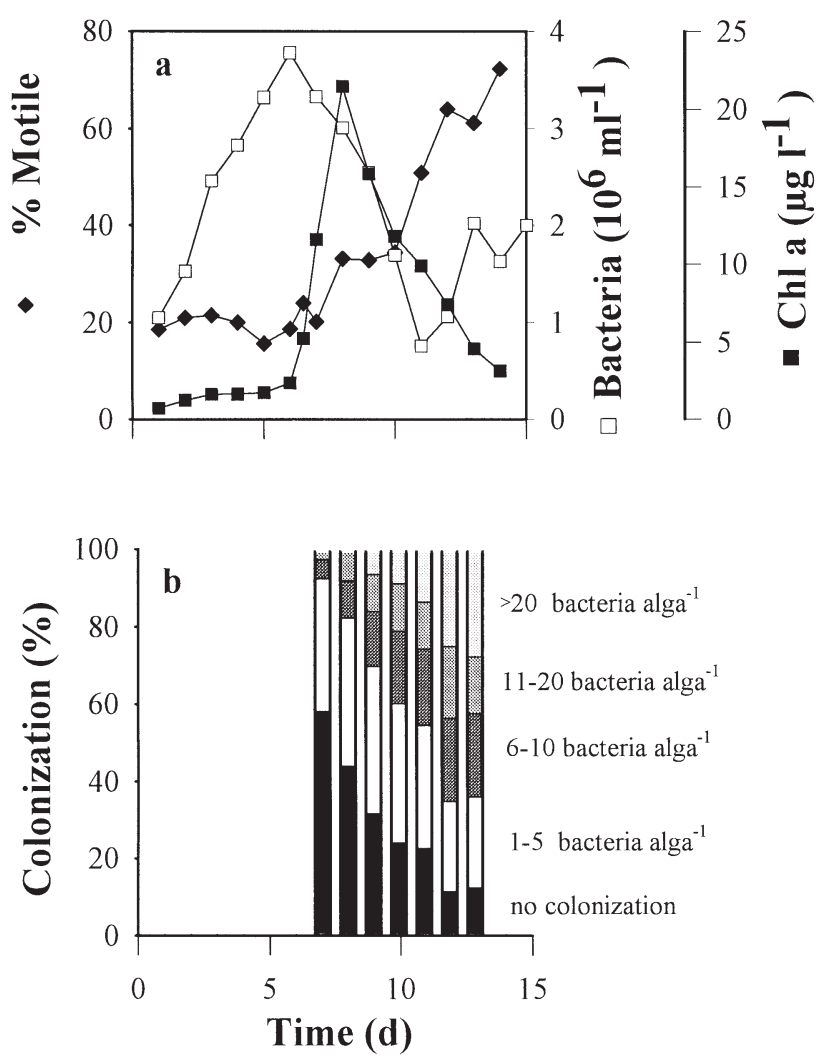

Fig. 8. Changes in (a) bacterial motility (\% motile), bacterial abundance, and chl a as well as (b) colonization rate (colonization \%) of algal cells throughout a mesocosm experiment (Tank 2)

\section{DISCUSSION}

We have shown that motility can be a broadly expressed phenotype of pelagic bacteria $(\%$ motile $=$ $\sim 40$ to $65 \%$ ), which can be sustained for months. We also recorded sustained periods of low \% motile (5 to $10 \%)$. Our study raises several questions: why was high \% motile not detected in previous studies? What causes the observed large variability of \% motile? What is the adaptive value of motility for bacteria in the pelagic ocean? What is the biogeochemical significance of motility and its variability?

\section{Relationship to previous studies}

Previous studies may have missed high \% motile simply because they happened to sample during periods of low \% motile. This is plausible since only few studies have been conducted thus far, none long-term. Previous studies may also have underestimated \% motile if, as here, bacteria were only intermittently motile; if observed for $<1 \mathrm{~min}$, some motile bacteria would be scored non-motile. Attachment to microscope slides is another potential source of underestimation. To minimize it we used depression slides and discarded each aliquot after observing a single microscope field for $1 \mathrm{~min}$. The underestimation was probably small since the same method yielded both very low $(<5 \%)$ and very high $(78 \%) \%$ motile. It is remarkable that \% bacteria expressing motility in natural assemblages were sustained for months at either low or high levels.

Most sampling was done at 1 site, so we have no direct basis for generalizing our findings to other sites. However, plankton conditions off the Scripps Pier broadly reflect those in the Southern California Bight (e.g. Eppley 1986). Further, the high and low \% motile persisted for months despite extensive mixing of water masses known to occur in the region; thus, the persistence of high or low \% motile may reflect a larger water mass. Finally, the \% motile was not correlated with the tidal cycle (not shown). These considerations suggest that our observations may, in fact, represent a mesoscale phenomenon. This is consistent with high \% motile (51 to $64.6 \%$ ) at stations up to 4 miles $(6.4 \mathrm{~km})$ offshore, and at 0.5 to $15 \mathrm{~m}$ depth, during a period when bacteria at Scripps Pier had similarly high \% motile $(63.7 \%)$. While it is logistically prohibitive to make frequent, long-term, synoptic observations of live samples over a broad ocean area, future sitespecific studies at varied locations could help determine the spatial and temporal patterns of bacterial motility in relation to environmental parameters. High $\%$ motile $(\leq 80 \%)$ was also observed in a later study by one of us (Grossart unpubl.) during a dinoflagellate bloom in coastal waters of Kattegat, southern Sweden, as well as in a study (Fenchel 2001) published since the submission of this paper.

\section{Bacterial behavior}

Our rough estimates of the speed of individual cells showed it to be highly variable $\left(<10\right.$ to $\left.>500 \mu \mathrm{m} \mathrm{s}^{-1}\right)$ and included bacteria showing reversals of direction as observed by Mitchell et al. (1995). Most bacteria in seawater are typically only $\leq 0.6 \mu \mathrm{m}$ in diameter and require high swimming speeds (ca $100 \mu \mathrm{m} \mathrm{s}^{-1}$; Mitchell et al. 1995) to counter reorientation due to Brownian motion, which increases with decreasing cell size with the third power of the cell radius (Berg 1982). In this study, cell speeds $>100 \mu \mathrm{m} \mathrm{s}^{-1}$ were common, although intermittent. Short and straight 'dart and stop' running is more efficient in a patchy environment than 'run and tumble' of enteric bacteria (Blackburn et al. 1997). Ces- 
sation of motility upon blending (from 56 to $0 \%$ ) suggests that motility is driven by flagella rotation. While flagellated bacteria are common among marine isolates (e.g. Leifson 1960), flagella have not been demonstrated in natural marine bacteria. We could not find any flagellated bacteria in seawater samples with the NanoOrange method (Grossart et al. 2000). It is unclear whether bacteria in the sea express flagella or whether they use some other means of motility.

\section{Control of motility}

\section{Temperature}

We considered that summer highs and winter lows in $\%$ motile were related to seawater temperature. However, this could not be supported, since (1) short-term temperature shifts of seawater samples, covering our field range $\left(15\right.$ to $\left.20^{\circ} \mathrm{C}\right)$, did not change $\%$ motile bacteria. Thus, temperature did not directly control \% motile. (2) Mesocosms were kept at a constant temperature $\left(17 \pm 1^{\circ} \mathrm{C}_{i}\right.$ ambient temperature $)$; yet, in the $14 \mathrm{~d}$ experiment \% motile rose from 13.7 to $77.0 \%$, spanning much of our field range. So, large variation in \% motile bacteria can occur independently of temperature, perhaps in the sea as well.

\section{Nutrients}

Is bacterial motility expressed in response to high DOM levels in seawater or, perhaps, to particulate point sources of DOM? How rapidly is it expressed? Enriching seawater with DOM or POM influenced bacterial motility, but the response varied with the concentration and the type of organic matter (Figs $3 \& 4$ ) as well as with the species of bacteria (Fig. 5). Glucose and/or peptone did not increase $\%$ motile in $\leq 1 \mathrm{~h}$; however, it prolonged the fraction of the time bacteria were motile. Long incubations (up to $21 \mathrm{~h}$ ) did result in high $\%$ motile $(\leq 83 \%)$. Whether enrichment increased motility of the existing assemblage or whether it is caused by dominance of motile species was not determined. In either case, our results suggest that microzones producing high levels of DOM (e.g. aggregates or phytoplankton) would harbor high $\%$ motile bacteria.

\section{Grazing}

There was no correlation between abundance of heterotrophic nanoflagellates and \% motile throughout the season. But there was a positive correlation between both variables throughout the diel study indicating that \% motile can increase in the presence of heterotrophic nanoflagellates. This is in contrast to the finding that motile bacteria will encounter their predators at higher rates as compared to non-motile bacteria (Blackburn et al. 1997). Recently, it was shown that in contrast to low velocity swimming, high velocity swimming of bacteria can reduce protozoan grazing of bacteria. On the other hand, heterotrophic nanoflagellates produce POM and DOM (Pelegrí et al. 1999) which may increase \% motile bacteria.

\section{Phytoplankton and detritus}

The diel pattern (Fig. 2) with daytime increase and nighttime decrease in \% motile suggested that bacterial motility is related to phytoplankton photosynthesis. However, seawater sampled during the day and incubated either in the light or in the dark yielded similar $\%$ motile, suggesting that motility was not responsive to de novo primary production. Perhaps the diel pattern reflects variations in metabolic (e.g. 'exudation'), physiological (e.g. phytoplankton autolysis) or trophic (e.g. 'sloppy feeding'; viral lysis) processing of the fixed carbon. Thus, \% motile during the diel study showed a strong positive correlation with POC $\left(\mathrm{r}^{2}=\right.$ $0.82)$ but a negative correlation with chl $a\left(\mathrm{r}^{2}=0.64\right)$. So, motility may be responsive to the concentration of total POC (living + detrital) and not phytoplankton alone. This is consistent with a decrease in \% motile (Fig. 3) in seawater filtered through $1.0 \mu \mathrm{m}$ filter. Further, incubating $1 \mu \mathrm{m}$ filtered seawater with either living or lysed Thalassiosira weissflogii greatly enhanced $\%$ motile (Fig. 4a) as well as \% attached bacteria (especially in the sample receiving lysed $T$. weissflogii; Fig. 4c). In both experiments \% motile was not initially reduced and it gradually decreased over time. Hence, we can rule out the possibility that pre-filtration (1.0 $\mu \mathrm{m}$ Nuclepore filters) reduced \% motile by loss of flagella due to increased shear. The response of bacterial motility to POC (fresh phytodetritus) in mesocosms, below, further supports that high \% motile results from sustained exposure of bacterial assemblage to high abundance of particulate loci of organic matter. However, the 3 isolates receiving lysed $T$. weissflogii responded very differently; 1 (LHAT 5 ) became nonmotile (Fig. 5a).

\section{Bacterial motility during phytoplankton 'bloom and bust'}

Our field and laboratory observations suggest that the nature and concentration of organic matter pool, as 
well as bacterial species composition, controls bacterial motility. However, mixing, water mass exchange, and trophodynamic complexity confound the interpretation of field data. Some problems can be overcome by studying phytoplankton blooms in mesocosms; they offer 'captive' systems undergoing sequential changes in organic matter production and processing. We could thus study motility response to broad features of the bloom and its decay, as well as draw inferences on the role of bacterial motility in bacteria-phytoplankton and bacteria-detritus interactions. General features of bacteria-mediated carbon dynamics and bacterial species variations during the mesocosm experiment have been published (Riemann et al. 2000).

The initial rise in \% motile bacteria lagged behind the chl $a$ increase by Day 2 to 3 but coincided with, and paralleled, the increase in detrital POC (Fig. 6). Presumably, the detrital POC increased as the phytoplankton bloom became $\mathrm{P}, \mathrm{N}$ limited and began to decay. The strong bacterial motility response to the bloom's death phase is consistent with motility enhancement of natural assemblages by diatom detritus or DOM (Fig. 4). What caused the bloom's demise was not studied, but the causes may include viral lysis, protozoan grazing, autolysis (due to competition with bacteria during nutrient depletion?), and bacterial ectoenzymatic attack on (nutrient stressed?) algae.

Depletion of dissolved inorganic phosphorus (DIP) and nitrogen (DIN) at the peak of the phytoplankton bloom (Day 9), may have resulted in enhanced competition with bacteria for DIP and DIN (e.g. P limitation indicated by a peak in alkaline phosphatase; Day 8). Not only did a larger fraction of free bacteria become motile during P limitation but also there was: (1) an intensification of bacterial colonization of phytoplankton; and (2) a sharp increase in detrital POC. These findings are consistent with the hypothesis (Azam \& Smith 1991) and supporting work (Grossart 1999) that bacteria-phytoplankton interaction can change from symbiosis (phycosphere as remineralization hot spot) to competition and then parasitism as nutrient-depletion becomes severe. Motility would be a prerequisite for such fluidity in bacteria-phytoplankton relationships.

Stimulation of bacterial motility by phytoplankton mortality is also seen in the fact that while \% motile rose with chl a during bloom development it did not decline with chl a during the bloom's demise. Phytodetritus apparently kept the \% motile at a high level (Fig. 6). Our results suggest the hypothetical scenario (Azam \& Smith 1991) that motility enables free bacteria to interact with phytoplankton and the interaction intensifies as phytoplankter die. Bacteria colonize the resulting POM, their 'sloppy hydrolysis' (Smith et al. 1992) turns POM into a point source of DOM, and this further intensifies motility among free bacteria. So, we would expect high \% motile to be diagnostic of tight bacteria-organic matter coupling, channeling large fractions of primary productivity, via bacteria-detritus interaction, into the microbial loop. On Day 12, attached bacteria peaked in their specific growth rates and protease and lipase activities. This is consistent with colonized detritus serving as: (1) a 'baby machine', releasing motile bacteria into seawater; and (2) a DOM point source, due to loose hydrolysis-uptake coupling on particles (Smith et al. 1992) and eliciting chemokinesis in free bacteria. This scenario leads to the prediction that high \% motile is typical of the early to late death phase of phytoplankton blooms.

\section{Motility as an indicator of active bacteria}

Generations of marine microbiologists have intensively investigated and passionately debated whether most bacteria in the ocean are 'active' or 'inactive'. A variety of operational criteria have been used for what constitutes an active bacterium, and corresponding approaches have been devised to 'interrogate' individual bacteria for their physiological state. Popular activity criteria are the ability to incorporate radiolabeled substrates (detected by microautoradiography, Hoppe 1976, Fuhrman \& Azam 1982) or to be actively respiring (detected e.g. by CTC, Rodriguez et al. 1992, or other indicators of an active electron transport system). Percent viable bacteria is measured, e.g. by the nalidixic acid method (Kogure et al. 1979) and, recently, by a method to detect bacterial nucleoid (Zweifel \& Hagström 1995).

Motility may serve as an indicator of viable and active bacteria, provided we accept that a motile bacterium is neither dead nor inactive. Obviously, a motile bacterium must be alive, but whether it is 'active' depends on the level of a given activity consistent with the context of the enquiry. We think since motility requires significant metabolic energy it is a suitable criterion for active bacteria. Then, our finding of protracted periods of high or low \% motile would contradict the generalization that most bacteria in the ocean are dormant or dead. A comparison of motile and CTCpositive bacteria in natural assemblages in 2 studies showed that \% CTC-positive were 82 and $86 \%$ lower than \% motile bacteria. Percent NucC (1 study) was $45 \%$ lower than $\%$ motile.

We considered that since motile bacteria must be respiring, the large difference between \% CTC-positive and \% motile is due to a difference in the methods' sensitivity. So, if we increased the cell-specific respiration of a natural assemblage by enrichment $\left(1 \mathrm{~g} \mathrm{l}^{-1}\right.$ peptone $; 16 \mathrm{~h}$ ) then \% CTC-positive and \% motile might converge. Indeed, they did: $91.1 \%$ for CTC- 
positive and $85.5 \%$ for $\%$ motile. Since $\%$ motile may be a more sensitive indicator of respiration, could it be used as a proxy for \% respiring bacteria? Generally not, because, while all motile bacteria are respiring, the opposite is not necessarily true. However, in instances where \% motile is higher than \% CTCpositive, one might consider using $\%$ motile as a proxy for $\%$ respiring bacteria. We also note that motility is easy to measure.

In conclusion, we have demonstrated that bacterial motility in the sea can be a commonly expressed phenotype, with the potential to optimize bacterial interaction with detritus and living organisms. The resulting spatially intimate and environmentally responsive coupling of bacteria in microzones has important consequences for carbon cycling and storage in the ocean. Microscale activities of bacteria have implications for ocean-basin scale processes as well (Azam 1998). We suggest that the consequences of bacterial motility for the food web and carbon cycling should be incorporated into models of the ocean's biogeochemical dynamics.

Acknowledgements. We thank Grieg Steward for significant contribution to the mesocosm experiment. Many thanks to Richard Long, Forest Rohwer, and Kay Bidle for numerous discussions and technical support. Meinhard Simon and 2 anonymous reviewers provided valuable critique. This work was supported by a postdoctoral fellowship from the German Science Foundation (DFG) to H.-P.G., and by an NSF grant (OCE9819603) and an NIH/NAID grant (RO1 A146600-01) to F.A.

\section{LITERATURE CITED}

Azam F (1998) Microbial control of oceanic carbon flux: The plot thickens. Science 280:694-696

Azam F, Ammerman JW (1984) Cycling of organic matter by bacterioplankton in pelagic marine ecosystems: microenvironmental considerations. In: Fasham MJR (ed) Flows of energy and materials in marine ecosystems. Plenum Publ Corp, New York, p 345-360

Azam F, Smith DC (1991) Bacterial influence on the variability in the ocean's biogeochemical state: a mechanistic view. In: Demers S (ed) Particle analysis in oceanography. NATO ASI Series, Springer-Verlag, Berlin

Bell W, Mitchell R (1972) Chemotactic and growth responses of marine bacteria to algal extracellular products. Biol Bull 143:265-277

Berg HC (1993) Random walks in biology, Expanded edn Princeton University Press, Princeton, NJ

Biddanda BA, Pomeroy LR (1988) Microbial aggregation and degradation of phytoplankton-derived detritus in seawater. I. Microbial succession. Mar Ecol Prog Ser 42:79-89

Blackburn N, Azam F, Hagström §̊ (1997) Spatially explicit simulations of a microbial food web. Limnol Oceanogr 42: $613-622$

Bowen JD, Stolzenbach KD, Chisholm SW (1993) Simulating bacterial clustering around phytoplankton cells in a turbulent ocean. Limnol Oceanogr 38:36-51
Bratbak G, Heldal M, Thingastad TF, Riemann B, Haslund $\mathrm{OH}$ (1992) Incorporation of viruses into the budget of microbial C-transfer. A first approach. Mar Ecol Prog Ser 83(2-3):273-280

Choi JW, Sherr EB, Sherr BF (1996) Relation between presence-absence of a visible nucleoid and metabolic activity in bacterioplankton cells. Limnol Oceanogr 51:1161-1168

Eppley RW (1986) Plankton dynamics of the Southern California Bight. Lecture notes on coastal and estuarine studies. Springer Verlag, Berlin

Fenchel T (2001) Eppur si muove: many water column bacteria are motile. Aquat Microb Ecol 24:197-201

Fuhrman JA, Azam F (1982) Thymidine incorporation as a measure of heterotrophic bacterioplankton production in marine surface waters: evaluations and field results. Mar Biol 66:109-120

Grosssart HP (1999) Interactions between marine bacteria and axenic diatoms (Cylindrotheca fusiformis, Nitzschia laevis, and Thallasiosira weissflogii) incubated under various conditions in the lab. Aquat Microb Ecol 19(1):1-11

Grossart HP, Steward GF, Martinez J, Azam F (2000) A simple, rapid method for demonstrating bacterial flagella. Appl Environ Microbiol 66(8):3632-3636

Guillard RRL (1975) Culture of phytoplankton for feeding marine invertebrates. In: Smith WL, Chanley MH (eds) Culture of marine invertebrate animals. Plenum Press, New York

Hoppe HG (1976) Determination and properties of actively metabolizing heterotrophic bacteria in the sea, investigated by means of micro-autoradiography. Mar Biol 36: 291-302

Jespersen AM, Christoffersen K (1987) Measurements of chlorophyll-a from phytoplankton using ethanol as extraction solvent. Arch Hydrobiol 109:445-454

Kirchman D, K'Nees E, Hodson R (1985) Leucine incorporation and its potential as a measure of protein synthesis by bacteria in natural aquatic systems. Appl Environ Microbiol 49:599-607

Kogure K, Shimidu U, Taga N (1979) A tentative direct microscopic method for counting living marine bacteria. Can J Microbiol 25:415-420

Lee S, Fuhrman JA (1987) Relationship between biovolume and biomass of naturally derived marine bacterioplankton. Appl Environ Microb 53:1298-1303

Leifson E (1960) Atlas of bacterial flagellation. Academic Press, New York and London

Matz C, Jürgens K (2001) The role of bacterial phenotypic traits in bacteria-flagellate interactions: which is the most effective mechanism. 9th International Symposium on Microbial Ecology, 26-31 August 2001, Amsterdam, p 157 (Abstract only)

Mitchell JG, Pearson L, Bonazinga A, Dillon S, Khouri H, Paxinos R (1995) Long lag times and high velocities in the motility of natural assemblages of marine bacteria. Appl Environ Microbiol 61:877-882

Mitchell JG, Pearson L, Dillon S (1996) Clustering of marine bacteria in seawater enrichments. Appl Environ Microbiol 62:3716-3721

Monger BC, Landry MR, Brown SL (1999) Feeding selection of heterotrophic marine nanoflagellates based on the surface hydrophobicity of their picoplankton prey. Limnol Oceanogr 44(8):1917-1927

Pelegrí SP, Christaki U, Dolan F, Rassoulzadegan F (1999) Particulate and dissolved organic carbon production by the heterotrophic nanoflagellate Pteridomonas danica Patterson and Fenchel. Microb Ecol 37:276-284

Porter KG, Feig YS (1980) DAPI for identifying and counting 
aquatic microflora. Limnol Oceanogr 25:943-948

Riemann L, Steward GF, Azam F (2000) Dynamics of bacterial community composition and activity during a mesocosm diatom bloom. Appl Environ Microbiol 66:578-587

Rodriguez GG, Phipps D, Ishiguro K, Ridgway HF (1992) Use of a fluorescent redox probe for direct visualization of actively respiring bacteria. Appl Environ Microbiol 58: 1801-1808

Simon M, Azam F (1989) Protein content and protein synthesis rates of planktonic marine bacteria. Mar Ecol Prog Ser 51:201-213

Simon M, Alldredge AL, Azam F (1990) Bacterial carbon dynamics on marine snow. Mar Ecol Prog Ser 65:205-211

Smith DC, Azam F (1992) A simple, economical method for

Editorial responsibility: James Hollibaugh,

Athens, Georgia, USA measuring bacterial protein synthesis rates in seawater using ${ }^{3} \mathrm{H}$-leucine. Mar Microb Food Webs 6:107-114

Smith DC, Simon M, Alldredge AL, Azam L (1992) Intense hydrolytic enzyme activity on marine aggregates and its significance for rapid particle solubilization in the sea. Nature 359:139-142

Stocker BAD, Campell JC (1959) The effect of non-lethal deflagellation on bacterial motility and observations on flagellar regeneration. J Gen Microbiol 20:670-685

ZoBell CE (1946) Marine biology. Cronica Botanica, Waltham, MA

Zweifel UL, Hagstöm Å (1995) Total counts of marine bacteria include a large fraction of non-nucleoid-containing bacteria (ghosts). Appl Environ Microbiol 61:2180-2185

Submitted: July 16, 2001; Accepted: July 30, 2001

Proofs received from author(s): September 13, 2001 